\title{
ReSEARCh Article \\ Coinoculaton of endophytic diazotroph with PGPR and AM fungi for enhancing sugarcane production
}

\author{
E. Jamuna, S. Thiruvarassan and P. Sridhar
}

\section{SUMMARY}

The field experiment was conducted at Sugarcane Research Station, Cuddalore during 2010 - 2012, to evaluate the response of sugarcane variety $\mathrm{CoC} 24$ to the application of bioinoculants viz., Gluconoacetobacter diazotrophicus, AM fungi and Azophos (Azospirillum and phosphobacteria), under different levels of N, $\mathrm{P}_{2} \mathrm{O}_{5}$ and $\mathrm{K}_{2} \mathrm{O}$ inorganic fertilizer in plant and ratoon crop. The results revealed that the application of mycorrhizae, G. diazotrophicus, Azospirillum and phosphobacteria significantly produced higher cane yield in plant crop. The application of Gluconoacetobacter diazotrophicus@10 kg+AM fungi+Azophos@10 kg+75\% NPK recorded the maximum germination and tiller population and also maximum mean millable cane population of 1.32 lakhs $/ \mathrm{ha}$, cane yield $(137.45 \mathrm{t} / \mathrm{ha})$ and sugar yield (16.96 t/ha). Similar results were recorded with the ratoon crop. The population of Azospirillum and Pseudomonas are higher compared to that of Glucanoacetobacter diazotrophicus and phosphobacteria. The application of bioinoculants improves soil microbial biomass and their by enhancing soil organic matter content. The applied bacterial sources helps in nitrogen fixation and also in continuous mobilizing and solubilisation of nutrients and their persistence and colonization in soil is an added advantage and also enhances the soil fertility. The usage of these bioinoculants inturn reduces the inorganic fertilizer input and thereby reduces the cost of cultivation.

Key Words : Sugarcane, Growth, Yield attributes, Nitrogen fixing bacteria, Phosphorous solubilising, Phosphobacteria, Mobilizing, AM fungi, Yield parameters

How to cite this article : Jamuna, E., Thiruvarassan, S. and Sridhar, P. (2021). Coinoculaton of endophytic diazotroph with PGPR and AM fungi for enhancing sugarcane production. Internat. J. Plant Sci., 16 (AAEBSSD): 1-6, DOI: 10.15740/HAS/IJPS/16.AAEBSSD/ 1-6, Copyright@2021: Hind Agri-Horticultural Society.

Article chronicle : Received : 05.07.2021; Revised : 07.07.2021; Accepted : 10.07.2021

\section{MEMBERS OF THE RESEARCH FORUM}

Author to be contacted :

E. Jamuna, Oilseeds Research Station (TNAU) Tinidivanam (T.N.) India

Email : drjamuna@gmail.com, jamunae@tnau.ac.in

Address of the Co-authors:

S. Thiruvarassan and P. Sridhar, Oilseeds Research Station (TNAU) Tinidivanam (T.N.) India
$\mathrm{S}$ ugarcane is a very demanding crop as for a cane yield of $100 \mathrm{t} / \mathrm{ha}$ it removes about $205 \mathrm{~kg} \mathrm{~N}, 55 \mathrm{~kg}$ $\mathrm{P}_{2} \mathrm{O}_{5}, 275 \mathrm{~kg} \mathrm{~K} \mathrm{O}_{2}$ and a large amount of micronutrients from soil (Yaduvanshi and Yadav, 1990). Since its fertilizer consumption is higher than that of other crops it has negative effect on soil health in the long term. In order to sustain productivity major nutrients are 
provided each year at the recommended application rates of $150 \mathrm{~kg} / \mathrm{ha}$ of $\mathrm{N}$ and $60 \mathrm{~kg}$ each of $\mathrm{P}_{2} \mathrm{O}_{5}$ and $\mathrm{K}_{2} \mathrm{O}$ for sugarcane. The efficiency of sugarcane to utilize $\mathrm{N}$ range between 16 and $45 \%$ as large quantities of applied $\mathrm{N}$ leach down through soil layer due to irrigation (Yadav and Prasad, 1992). Deteoration in the physico-chemical and biological properties of soil is considered to be the prime reason for declining sugarcane yield and productivity. The biofetilizer application increases crop growth through combination of BNF, growth promoting / hormonal substances, increased availability of soil nutrients and disease resistance. The importance of biofertilizer lies in the ability to supplement/ mobilize soil nutrients with minimal use of non renewable resources.

Johri (2006) reported that some of the sugarcane varieties have been found to derive upto $70 \%$ of their nitrogen requirement through biological nitrogen fixation. Since than various kinds of bacteria such as Glucanoacetobacter diazotrophicus, Herbaspirillum spp., Azospirillum amazonense, Burkholderia spp., capable of fixing nitrogen have been reported to colonize the epidermis of sugarcane stem and roots of which Glucanoacetobacter seems to contribute substantially to nitrogen nutrition of the plant (Dobereiner et al., 1995). G. diazotrophicus a nitrogen fixing endophyte is found in high number in all part of sugarcane $\left(10^{2}-10^{6}\right.$ per $g$ fresh weight) and its better colonization in sugarcane is probably due to tis capability to grow in the presence of high sugar and low $\mathrm{pH}$. Besides sugarcane it colonizes many other sugar and non sugar crops also. Production of plant growth hormones is the other beneficial trait associated with G. diazotrophicus (Sevilla et al., 1998). Field trials conducted in sugarcane with Glucano acetobacter diazotrophicus with other diazotrophs can match yield level equal to $275 \mathrm{~kg} \mathrm{~N} /$ ha application (Sevilla et al., 2001; Muthukumarasway et al., 2002; Oliveria et al., 2002).

In India where sugarcane occupies over 4 million / ha, interest in exploitation of such microbes has increased due to an increase in prices of chemical fertilizers following withdrawal of subsidy on them. Concerning the above problems the current study was focused on the use of bioinoculants to enhance the sugarcane growth and also to assess the functional potentialities in relation to plant growth promoting activities like IAA, phosphate solubilisation and nitrogenase activity with the following objectives of standardizing the efficient combination of bioinoculants for maximizing sugarcane productivity and exploring the possibility of reduction in inorganic fertilizer input through bioinoculant application.

\section{MATERIAL AND METHODS}

The experiment was conducted for a period of 2 year $(2010$ - 2012) at Sugarcane Research Station, Cuddalore with ten treatments with three replications in Randominised Block Design in plant and ratoon crop. The sugarcane variety taken for the study was CoC24. The mean maximum and minimum temperature of the location was $31.7^{\circ} \mathrm{C}$ and $24.1^{\circ} \mathrm{C}$, respectively. The mean annual rainfall was $1200 \mathrm{~mm}$. The soil of the experimental field was sandy clay loam, with low available N (186.84 $\left.\mathrm{kg} \mathrm{ha}^{-1}\right)$, medium in available ' $\mathrm{P}$ ' $\left(16.5 \mathrm{~kg} \mathrm{ha}^{-1}\right)$ and medium in available potash $\left(265 \mathrm{~kg} \mathrm{ha}^{-1}\right)$. The $\mathrm{pH}$ of the soil is 7.2. The bioinoculants viz., G. diazotrophicus, AM fungi and Azophos (Azospirillum and phospho bacteria) was used along with inorganic fertilizer.

The microbial inoculants were applied as soil application@10 kg/ha of G. diazotrophicus and Azophos, $25 \mathrm{~kg}$ of VAM / ha in two equal splits at $30^{\text {th }}$ and $60^{\text {th }}$ day after planting. The data collected on germination count, tiller population, millable cane population, cane yield commercial cane sugar per cent, sugar yield were pooled and analysed. The yield were recorded along with the quality parameters. The soil samples were collected at $45^{\text {th }}$ and $105^{\text {th }}$ day after planting of plant crop and ratoon crop. The population of bioinoculants was enumerated by pour plate technique (James 1958)

\section{RESULTS AND DISCUSSION}

The plant and the ratoon crop was raised during 2010-2012 with sugarcane variety CoC24. The microbial bioinoculants were applied as per the treatment schedule. The inorganic fertilizers were also applied as per schedule. Regarding germination and tiller counts, the application of Gluconoacetobacter diazotrophicus@10 kg + AM fungi@25 kg/ha+Azophos@10 kg+75\% NPK recorded higher germination of $87.36 \%$ and maximum tiller population of 1,94,185 / ha (Table 1). Application of G.diazotrophicus@10 kg/ha+AM fungi@25 kg/ha +Azophos@10 kg/ha+75\% of the recommended NPK also recorded significantly maximum mean millable cane population and cane yield with 1.32 lakhs /ha and $137.45 \mathrm{t} / \mathrm{ha}$, respectively, followed by the application of G. diazotrophicus@10kg+AM fungi@25kg/ha + Azophos@10 kg+100\%NPK with 1.29 lakhs millable cane/ha. The CCS\% and sugar yield also recorded 
Coinoculaton of endophytic diazotroph with PGPR \& AM fungi for enhancing sugarcane production

maximum with $10.7 \%$ and $16.96 \mathrm{t} / \mathrm{ha}$, respectively with the application of G. diazotrophicus@10kg/ha+AM fungi@25 kg/ha+Azophos@10 kg/ha+75\% of the recommended NPK (Table 2). As that of plant crop similar trend was observed with ratoon crop with maximum millable cane population of $1.22 \mathrm{lakhs} / \mathrm{ha}$ in plot treated with G. diazotrophicus@10 kg/ha+ AM fungi@25 kg/ha+Azophos@10 kg/ha+75\% of the recommended NPK (Table 2).

The treatment with G. diazotrophicus + AM fungi
+ Azophos $+75 \%$ NPK recorded the maximum population of G. diazotrophicus $\left(39.33 \times 10^{4} \mathrm{cfu} / \mathrm{ml}\right.$ and $\left.44.00 \times 10^{4} \mathrm{cfu} / \mathrm{ml}\right)$, Azospirillum $\left(35.33 \times 10^{4} \mathrm{cfu} / \mathrm{ml}\right.$ and x $\left.50.66 \times 10^{4} \mathrm{cfu} / \mathrm{ml}\right)$, phosphobacteria $\left(32.00 \times 10^{4} \mathrm{cfu} /\right.$ $\mathrm{ml}$ and $\left.41.00 \times 10^{4} \mathrm{cfu} / \mathrm{ml}\right)$ and Pseudomonas $\left(46.66 \times 10^{6}\right.$ $\mathrm{cfu} / \mathrm{ml}$ and $\left.\times 52.00 \times 10^{6} \mathrm{cfu} / \mathrm{ml}\right)$ at $45^{\text {th }}$ and $10^{5 \text { th }} \mathrm{DAP}$, respectively and similar trend was observed with ratoob crop also (Table 4 and 5).

The increase in yield and enhanced quality parameters was due to the combined effect of the

\begin{tabular}{|c|c|c|c|c|c|}
\hline \multirow[b]{2}{*}{ Sr. No. } & \multirow[b]{2}{*}{ Treatments } & \multicolumn{2}{|c|}{ Plant crop } & \multicolumn{2}{|c|}{ Ratoon crop } \\
\hline & & $\begin{array}{c}\text { Germination } \\
\text { percentage }\end{array}$ & $\begin{array}{c}\text { Tiller population } \\
(‘ 000 / \mathrm{ha})\end{array}$ & $\begin{array}{l}\text { Sprouting } \\
\text { percentage }\end{array}$ & $\begin{array}{c}\text { Tiller population } \\
\text { (‘000/ha) }\end{array}$ \\
\hline 1. & G. diazotrophicus $+75 \% \mathrm{NPK}$ & 82.93 & 178.72 & 85.93 & 180.72 \\
\hline 2. & AM fungi $+75 \% \mathrm{NPK}$ & 77.86 & 175.89 & 85.86 & 177.89 \\
\hline 3. & Azophos $+75 \%$ NPK & 84.09 & 179.21 & 86.09 & 183.21 \\
\hline 4. & G. diazotrophicus + AM fungi $+75 \% \mathrm{NPK}$ & 86.06 & 187.57 & 87.34 & 193.38 \\
\hline 5. & G. diazotrophicus + Azophos $+75 \%$ NPK & 86.71 & 188.29 & 89.51 & 190.29 \\
\hline 6. & AM fungi + Azophos $+75 \%$ NPK & 83.46 & 191.38 & 88.76 & 189.57 \\
\hline 7. & G. diazotrophicus + AM fungi + Azophos $+75 \%$ NPK & 87.36 & 194.11 & 94.25 & 196.11 \\
\hline 8. & G. diazotrophicus + AM fungi + Azophos $+100 \%$ NPK & 86.58 & 194.18 & 90.18 & 191.18 \\
\hline 9. & Recommended NPK (100\%) alone & 83.20 & 194.16 & 84.20 & 185.16 \\
\hline \multirow[t]{4}{*}{10.} & $75 \%$ of recomm ended NPK alone & 83.46 & 167.67 & 83.46 & 154.67 \\
\hline & Mean & 84.17 & 185.12 & 87.56 & 184.22 \\
\hline & S.Ed & 4.13 & 0.22 & 4.13 & 0.32 \\
\hline & $\mathrm{CD}(0.05)$ & 8.67 & 0.46 & 8.67 & 0.58 \\
\hline
\end{tabular}

\begin{tabular}{|c|c|c|c|c|c|}
\hline Sr. No. & Treatments & $\begin{array}{c}\text { Millable cane } \\
\text { population (' } 000 / \text { ha.) }\end{array}$ & $\begin{array}{l}\text { Cane yield } \\
\text { ('000/ha.) }\end{array}$ & $\mathrm{CCS} \%$ & $\begin{array}{c}\text { Sugar yield } \\
(\mathrm{t} / \mathrm{ha})\end{array}$ \\
\hline 1. & G. diazotrophicus $+75 \% \mathrm{NPK}$ & 120.0 & 126.12 & 9.92 & 12.51 \\
\hline 2. & AM fungi $+75 \% \mathrm{NPK}$ & 117.2 & 123.56 & 9.72 & 12.01 \\
\hline 3. & Azophos $+75 \%$ NPK & 118.7 & 125.79 & 9.80 & 12.33 \\
\hline 4. & G.diazotrophicus + AM fungi $+75 \%$ NPK & 124.8 & 131.25 & 10.34 & 13.57 \\
\hline 5. & G.diazotrophicus + Azophos $+75 \%$ NPK & 123.5 & 130.55 & 10.22 & 13.34 \\
\hline 6. & AM fungi + Azophos $+75 \%$ NPK & 121.2 & 129.84 & 9.95 & 12.92 \\
\hline 7. & G.diazotrophicus + AM fungi + Azophos $+75 \%$ NPK & 132.4 & 137.45 & 10.70 & 14.96 \\
\hline 8. & G.diazotrophicus + AM fungi + Azophos $+100 \%$ NPK & 125.2 & 133.62 & 10.50 & 14.03 \\
\hline 9. & Recommended NPK (100\%) alone & 120.8 & 128.19 & 10.50 & 12.88 \\
\hline \multirow[t]{4}{*}{10.} & $75 \%$ of recommen ded NPK alone & 95.70 & 107.15 & 10.05 & 10.52 \\
\hline & Mean & 119.95 & 127.352 & 10.17 & 12.907 \\
\hline & SEd & 4.21 & 3.55 & 0.99 & 0.68 \\
\hline & $\mathrm{CD}$ & 8.47 & 7.14 & NS & 1.38 \\
\hline
\end{tabular}


E. Jamuna, S. Thiruvarassan and P. Sridhar

\begin{tabular}{|c|c|c|c|c|c|}
\hline Sr. No. & Treatments & $\begin{array}{c}\text { Millable cane population } \\
\text { ('000/ha.) }\end{array}$ & $\begin{array}{l}\text { Cane yield } \\
\text { ('000/ha.) }\end{array}$ & $\mathrm{CCS} \%$ & Sugar yield \\
\hline 1. & G. diazotrophicus $+75 \% \mathrm{NPK}$ & 116.20 & 118.42 & 10.37 & 12.05 \\
\hline 2. & AM fungi $+75 \% \mathrm{NPK}$ & 114.25 & 115.86 & 10.17 & 11.55 \\
\hline 3. & Azophos $+75 \%$ NPK & 115.7 & 118.09 & 10.25 & 11.87 \\
\hline 4. & G. diazotrophicus + AM fungi $+75 \% \mathrm{NPK}$ & 117.8 & 123.55 & 10.79 & 13.11 \\
\hline 5. & G.diazotrophicus + Azophos $+75 \% \mathrm{NPK}$ & 117.0 & 122.85 & 10.67 & 12.88 \\
\hline 6. & AM fungi + Azophos $+75 \%$ NPK & 115.8 & 122.14 & 10.4 & 12.46 \\
\hline 7. & G.diazotrophicus + AM fungi + Azophos $+75 \%$ NPK & 122.4 & 129.75 & 11.15 & 14.5 \\
\hline 8. & G.diazotrophicus + AM fungi + Azophos $+100 \%$ NPK & 118.2 & 125.92 & 10.95 & 13.57 \\
\hline 9. & Recommended NPK (100\%) alone & 116.5 & 120.49 & 10.95 & 12.42 \\
\hline \multirow[t]{4}{*}{10.} & $75 \%$ of recommended NPK alone & 89.70 & 99.45 & 10.5 & 10.06 \\
\hline & Mean & 114.36 & 119.65 & 10.62 & 12.45 \\
\hline & SEd & 6.37 & 5.13 & 0.86 & 0.21 \\
\hline & $\mathrm{CD}$ & 13.38 & 11.07 & NS & 0.58 \\
\hline
\end{tabular}

\begin{tabular}{|c|c|c|c|c|c|c|c|c|}
\hline \multirow{2}{*}{ Treatments } & \multicolumn{2}{|c|}{$\begin{array}{l}\text { Azospirillum } \\
\left(\mathrm{x} 10^{5} \mathrm{cfu} / \mathrm{ml}\right)\end{array}$} & \multicolumn{2}{|c|}{$\begin{array}{l}\text { G. diazotrophicus } \\
\left(\mathrm{x} 10^{4} \mathrm{cfu} / \mathrm{ml}\right)\end{array}$} & \multicolumn{2}{|c|}{$\begin{array}{l}\text { Phosphobacteria } \\
\left(\times 10^{4} \mathrm{cfu} / \mathrm{ml}\right)\end{array}$} & \multicolumn{2}{|c|}{$\begin{array}{c}\text { Pseudomonas } \\
\left(\mathrm{x} 10^{6} \mathrm{cfu} / \mathrm{ml}\right)\end{array}$} \\
\hline & $\begin{array}{l}45^{\text {th }} \\
\text { DAP }\end{array}$ & $\begin{array}{l}105^{\text {th }} \\
\text { DAP }\end{array}$ & $\begin{array}{l}45^{\text {th }} \\
\text { DAP }\end{array}$ & $\begin{array}{l}105^{\text {th }} \\
\text { DAP }\end{array}$ & $\begin{array}{l}45^{\text {th }} \\
\text { DAP }\end{array}$ & $\begin{array}{l}105^{\text {th }} \\
\text { DAP }\end{array}$ & $\begin{array}{l}45^{\text {th }} \\
\text { DAP }\end{array}$ & $\begin{array}{l}105^{\text {th }} \\
\text { DAP }\end{array}$ \\
\hline G. diazotrophicus $+75 \% \mathrm{NPK}$ & 35.66 & 54.00 & 28.02 & 49.00 & 10.66 & 19.66 & 35.66 & 40.33 \\
\hline $\mathrm{AM}$ fungi $+75 \% \mathrm{NPK}$ & 26.66 & 35.66 & 19.66 & 26.00 & 9.50 & 20.75 & 39.00 & 44.15 \\
\hline Azophos $+75 \%$ NPK & 36.00 & 50.33 & 15.33 & 22.50 & 20.00 & 32.00 & 37.66 & 41.70 \\
\hline G.diazotrophicus + AM fungi $+75 \%$ NPK & 36.77 & 49.00 & 22.33 & 40.33 & 10.33 & 19.00 & 41.66 & 45.50 \\
\hline G.diazotrophicus + Azophos $+75 \%$ NPK & 41.00 & 50.50 & 23.16 & 39.33 & 18.50 & 28.66 & 37.66 & 45.00 \\
\hline AM fungi + Azophos $+75 \%$ NPK & 39.66 & 47.33 & 16.67 & 27.66 & 15.66 & 25.66 & 40.33 & 40.33 \\
\hline G.diazotrophicus + AM fungi + Azophos $+75 \%$ NPK & 43.33 & 68.33 & 26.66 & 45.66 & 20.33 & 30.00 & 46.66 & 52.00 \\
\hline G.diazotrophicus + AM fungi + Azophos $+100 \%$ NPK & 39.66 & 59.00 & 25.12 & 44.66 & 19.66 & 28.66 & 42.66 & 49.00 \\
\hline Recommended NPK (100\%) alone & 24.66 & 36.33 & 10.66 & 15.66 & 6.66 & 15.33 & 20.66 & 23.66 \\
\hline \multirow[t]{2}{*}{$75 \%$ of recommended NPK alone } & 25.00 & 30.66 & 12.50 & 19.50 & 4.13 & 14.00 & 20.00 & 28.66 \\
\hline & 34.84 & 48.11 & 19.21 & 35.53 & 10.06 & 21.77 & 36.20 & 41.03 \\
\hline
\end{tabular}

\begin{tabular}{|c|c|c|c|c|c|c|c|c|}
\hline \multirow{2}{*}{ Treatments } & \multicolumn{2}{|c|}{$\begin{array}{l}\text { Azospirillum } \\
\left(\mathrm{x} 10^{5} \mathrm{cfu} / \mathrm{ml}\right)\end{array}$} & \multicolumn{2}{|c|}{$\begin{array}{l}\text { G. diazotrophicus } \\
\left(\mathrm{x} 10^{4} \mathrm{cfu} / \mathrm{ml}\right)\end{array}$} & \multicolumn{2}{|c|}{$\begin{array}{l}\text { Phosphobacteria } \\
\left.\text { (x } 10^{4} \mathrm{cfu} / \mathrm{ml}\right)\end{array}$} & \multicolumn{2}{|c|}{$\begin{array}{l}\text { Pseudomonas } \\
\left(\mathrm{x} 10^{6} \mathrm{cfu} / \mathrm{ml}\right)\end{array}$} \\
\hline & $\begin{array}{l}45^{\text {th }} \\
\text { DAP }\end{array}$ & $\begin{array}{l}105^{\text {th }} \\
\text { DAP }\end{array}$ & $\begin{array}{l}45^{\text {th }} \\
\text { DAP }\end{array}$ & $\begin{array}{l}105^{\text {th }} \\
\text { DAP }\end{array}$ & $\begin{array}{l}45^{\text {th }} \\
\text { DAP }\end{array}$ & $\begin{array}{l}105^{\text {th }} \\
\text { DAP }\end{array}$ & $\begin{array}{l}45^{\text {th }} \\
\text { DAP }\end{array}$ & $\begin{array}{l}105^{\text {th }} \\
\text { DAP }\end{array}$ \\
\hline G. diazotrophicus $+75 \% \mathrm{NPK}$ & 37.16 & 57 & 28.77 & 50 & 12.66 & 22.66 & 37.66 & 44.33 \\
\hline AM fung $i+75 \% \mathrm{NPK}$ & 28.16 & 38.66 & 20.41 & 27 & 11.5 & 23.75 & 41 & 48.15 \\
\hline Azophos $+75 \%$ NPK & 37.5 & 53.33 & 16.08 & 23.5 & 22 & 35 & 39.66 & 45.7 \\
\hline G.diazotrophicus + AM fungi $+75 \%$ NPK & 38.27 & 52 & 23.08 & 41.33 & 12.33 & 22 & 43.66 & 49.5 \\
\hline G.diazotrophicus + Azophos $+75 \%$ NPK & 42.5 & 53.5 & 23.91 & 40.33 & 20.5 & 31.66 & 39.66 & 49 \\
\hline AM fungi + Azophos $+75 \%$ NPK & 41.16 & 50.33 & 17.42 & 28.66 & 17.66 & 28.66 & 42.33 & 44.33 \\
\hline G.diazotrophicus + AM fungi + Azophos $+75 \%$ NPK & 44.83 & 71.33 & 27.41 & 46.66 & 22.33 & 33 & 48.66 & 56 \\
\hline G.diazotrophicus + AM fungi + Azophos $+100 \%$ NPK & 41.16 & 62 & 25.87 & 45.66 & 21.66 & 31.66 & 44.66 & 53 \\
\hline Recommend ed NPK (100\%) alone & 26.16 & 39.33 & 11.41 & 16.66 & 8.66 & 18.33 & 22.66 & 27.66 \\
\hline \multirow[t]{2}{*}{$75 \%$ of recommended NPK alone } & 26.5 & 33.66 & 13.25 & 20.5 & 6.13 & 17 & 22 & 32.66 \\
\hline & 36.34 & 51.11 & 20.76 & 34.03 & 15.54 & 26.37 & 38.20 & 45.03 \\
\hline
\end{tabular}


bioinoculants along with the inorganic fertilizers. The biofertilizers application enhanced the yield and quality parameters and also essential to maintain soil microflora population and protect soil fertility from deterioration. Significant changes in various plant growth parameters have been shown by the inoculation of various nitrogen fixing and plant growth promoting bacteria (Nayak et al., 1986; Murty and Ladha, 1988 and Gunarto et al., 1999). Sevilla et al (1998), have shown the benefits to sugarcane growth by using Nif - mutants of Acetobacter. In addition to nitrogen fixation the beneficial effects has been attributed to the production of plant growth hormones also (Glick, 1994).

Application of phosphorous from different sources $i e$. from inorganic and as bioinoculants (AM fungi and phosphobacteria) was found to be effective in sugarcane. Continuous availability of the valuable nutrients and their persistence and colonization in soil makes the soil more fertile and healthy. The mobilization of $\mathrm{P}$ from soil to the plants is mediated by hairy root systems of the mycorrhizal fungi through plant roots. It commonly infect plant roots, including those of sugarcane forming beneficial symbiotic relationships (Kelly et al., 1997). The improvement in plant growth was attributed to an enhanced access of mycorrhizal root to soil phosphorous located beyond the rhizosphere (Sanders and Tinker. 1973) and infection by mycorrhizal fungi is significantly rduced at high soil phosphorous levels (Amijee et al., 1989). Mycorrhiza was found to be compatible with nitrogen fixers viz., Rhizobium (Hayman, 1986), Acetobacter and phosphate solubilising bacteria (Singh and Kapoor, 1999). It also holds good for sugarcane.

\section{Conclusion:}

The inoculation of bioinoculants is beneficial for sugarcane growth for increasing the plant vigour at lower nitrogen levels, consequently the amount of fertilizer could be reduced. AM fungi and phosphobacteria are very much essential to convert the unavailable form of the phosphorous source to available source and providing to the plants. The usage of these bioinoculants inturn reduces the inorganic fertilizer input and thereby reduces the cost of cultivation. With this references these bioinoculants can be recommended for their use in nutrient management and enhanced sugarcane productivity.

\section{REFERENCES}

Amijee, F., Tinker, P.B. and Stribley, D.P. (1989). The development of endomycorrhizal root systems VII A detailed study of effects of soil phosphorous on colonisation. New phytol., 111: 453-446.

Glick, D.P. (1994). The enhancement of plant growth by free living bacteria. Canadian J.Microbiol., 41: 109-117.

Gunarto, L., Adchi, K. and Senboku, L. (1999). Isolation and selection of indigenous Azospirillum spp. from a subtropical island and effect if inoculation on growth of low land rice under several levels of $\mathrm{N}$ application. Biol. Fertile. Soils, 28 : 129-135.

Hayman, H. (1986). Response of sugarcane to silicate source and rate growth and yield. Phytopathology, 93(4): $402-412$.

Johri, H. (2006). Response of sugarcane to nitrogen source and rate of growth and yield. Agron. J., 74 : 481-484.

Kelly, R.M., Edwards, D.G., Magarey, R.C. and Thompson, J.P. (1997). The effect of VAM on the growth and nutrition of sugarcane. Proc. Aust. Soc. Sug. Cane Technol., 19 : 73-79.

Murthy, M.G. and Ladha, L.K.(1988). Influence of Azospirillum inoculation on the mineral uptake and growth of rice under hydrophonic conditions. Plant \& Soil, 108 : 281-285.

Muthukumarasamy, R., Revathy, G. and Loganathan, P. (2002). Effect of inorganic $\mathrm{N}$ on the population in vitro colonization and morphology of Acetobacter. Plant \& Soil, 243 : $91-102$.

Nayak, D.N., Ladha, L.K. and Watanabe, I. (1986). The fate of marker A. lipoferum inoculated and its effect on growth, yield and N fixation. Biol. Fertile. Soils, 2: 714.

Oliveria, A.L.M., Urquiaga, S., Dobrenier, J. and Baldani, J.I. (2002). The effect of inoculating endophytic $\mathrm{N}$ fixing bacteria on micropropogated sugarcane plants. Plant \& Soil, 242: 205-215.

Olsen, S.R., Cole, F., Watanabe, S. and Dean, A.L. (1954). Estimation of available phosphorus in soil by extraction with sodium bicarbonate. USDA. Circ., 939.

Sanders, F.E. and Ticker, P.B. (1973). Phosphate flow into mycorrhizal roots. Pesticide Science, 4 : 385-395.

Sevilla, M., Oliveria, D., Baldani, I. and Kenedy, C. (1998). Contributions of the bacterial endophyte of Acetobacter to sugarcane nutrition: a preliminary study. Symbiosis, 25 : 181-191. 
E. Jamuna, S. Thiruvarassan and P. Sridhar

Sevilla, M., Burris, R. H., Gunapala, N. and Kennedy, C. (2001). Comparison of benefits of sugarcane plant growth with Acetobacter inoculation in wild type and Nif mutant strains. Mol. Plant Microbe. Interaction., 14 : $358-366$.

Singh and Kapoor (1999). Silicon nutrition and sugarcane cultivation. J. Plant Nutr., 15 (7): 1-10.

Standford, S. and English, L. (1949). Use of flame photometer in rapid soil tests of K and Ca. Agron.J., 4:446-447.
Subbiah, B. V, and Asija, C.L. (1956). A rapid procedure for estimation of available nitrogen in soils. Curr. Sci., 25 : 259-260.

Yadav, S. and Prasad, H. (1992). Nitrogenase activity of sugarcane propagated from stem cuttings on sterile vermiculite. Soil Biol. Biochem., 12 : 413- 417.

Yaduvanshi and Yadhav (1990). Isolation and characterisation of genetically two distant group of Acetobacter from new host plant. J. Appl. Bacteriol., 86 : 1053-1058.

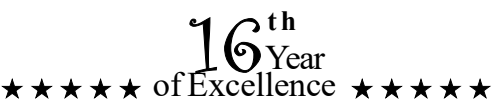

